\title{
Prevalence of malnutrition and associated factors in hemodialysis patients ${ }^{1}$
}

\author{
Prevalência de desnutrição e fatores associados \\ em pacientes em hemodiálise
}

Ana Tereza Vaz de Souza FREITAS 2

Inaiana Marques Filizola VAZ ${ }^{3}$

Sanzia Francisca FERRAZ ${ }^{4}$

Maria do Rosário Gondim PEIXOTO 5

Marta Isabel Valente Moraes CAMPOS ${ }^{3}$

\section{A B S T R A C T}

\section{Objective}

To assess the prevalence of malnutrition and associated factors in hemodialysis patients.

\section{Methods}

This is a cross-sectional study of 344 hemodialysis patients from Goiânia, Goiás aged 18 years or more. The dependent variable, malnutrition, was investigated by the Subjective Global Assessment. The independent variables included socioeconomic, demographic, and lifestyle data, clinical history, and energy and protein intakes. The patients underwent anthropometric measurements and laboratory tests. Multiple Poisson regression determined the associated factors $(p<0.05)$.

\section{Results}

Mild or moderate malnutrition was found in $22.4 \%$ of the patients. Malnourished patients had lower body mass index, mid-arm muscle circumference, percentage of body fat, serum creatinine $(p<0.001)$, and normalized protein nitrogen appearance $(p=0.001)$. Multivariate analysis identified the following factors associated with malnutrition: age between 19 and 29 years $(P R=1.23,95 \% \mathrm{Cl}=1.06-1.43)$, family income less than 2 minimum salaries $(P R=1.13,95 \% C l=1.01-1.27)$, hemodialysis vintage $\geq 60$ months $(P R=1.08,95 \% C l=1.01-1.16), K t N \geq 1.2$ $(\mathrm{RP}=1.12,95 \% \mathrm{Cl}=1.03-1.22)$, calorie intake $<35 \mathrm{kcal} / \mathrm{kg} /$ day $(\mathrm{PR}=1.22,95 \% \mathrm{Cl}=1.10-1.34)$, and normalized protein nitrogen appearance $<1.0 \mathrm{~g} / \mathrm{kg} /$ day $(\mathrm{PR}=1.13,95 \% \mathrm{Cl}=1.05-1.21)$.

${ }^{1}$ Article based on doctoral dissertation of ATVS FREITAS intitled "Prevalência e fatores associados à desnutrição e à obesidade abdominal em pacientes em hemodiálise na cidade de Goiânia-GO". Universidade Federal de Goiás; 2011.

2 Universidade Federal de Goiás, Faculdade de Nutrição. R. 227, Qd. 68, s/n., Setor Leste Universitário, 74605-080, Goiânia, GO, Brasil. Correspondência para/Correspondence to: ATVS FREITAS. E-mail: <nutrianna@hotmail.com>

${ }^{3}$ Universidade Federal de Goiás, Hospital das Clínicas, Departamento de Nutrição e Dietética. Goiânia, GO, Brasil.

${ }^{4}$ Secretaria Estadual de Saúde, Hospital de Doenças Tropicais. Goiânia, GO, Brasil.

5 Universidade Federal de Goiás, Faculdade de Nutrição, Programa de Pós-Graduação em Nutrição da Saúde. Goiânia, GO, Brasil. 


\section{Conclusion}

The prevalence of malnutrition in this population was high, corroborating the literature. The prevalence was higher in patients aged less than 29 years and those with low family income, longer hemodialysis vintage, higher $\mathrm{Kt} / \mathrm{N}$, and inadequate protein and calorie intakes. Strategies to reverse this situation should include more nutritional care.

Indexing terms: Malnutrition. Nutrition assessment. Renal dialysis.

\section{R E S U M O}

\section{Objetivo}

Avaliar a prevalência e os fatores associados à desnutrição em pacientes em hemodiálise.

\section{Métodos}

Estudo transversal com 344 pacientes maiores de 18 anos em hemodiálise em Goiânia, Goiás. A variável dependente, desnutrição, foi obtida por meio da avaliação subjetiva global. As variáveis independentes envolveram aspectos socioeconômicos, demográficos, estilo de vida, história clínica, ingestão energética e proteica. Realizaram-se antropometria e exames laboratoriais. A análise dos fatores associados foi realizada por regressão de Poisson múltipla $(p<0,05)$.

\section{Resultados}

A prevalência de desnutrição leve ou moderada foi constatada em 22,4\% dos pacientes. Os pacientes desnutridos apresentaram menor índice de massa corporal, menor circunferência muscular do braço, menor porcentagem de gordura corporal, menor valor de creatinina sérica $(p<0,001)$ e nPNA $(p=0,001)$. O resultado final da análise multivariada identificou os fatores associados à desnutrição: idade de 19 a 29 anos (RP=1,23; IC95\%=1,06-1,43), renda familiar $<2$ salários-mínimos $(R P=1,13 ;$ IC95\%=1,01-1,27), tempo em HD $\geq 60$ meses $(R P=1,08 ; I C 95 \%=1,01-1,16), K t / V \geq 1,2(R P=1,12 ; I C 95 \%=1,03-1,22)$, ingestão calórica inferior a $35 \mathrm{kcal} / \mathrm{kg} / \mathrm{dia}$ $(R P=1,22 ; I C 95 \%=1,10-1,34)$ e $n P N A<1,0$ g/kg/dia $(R P=1,13 ; I C 95 \%=1,05-1,21)$.

\section{Conclusão}

Observou-se alta prevalência de desnutrição na população estudada em acordo com o encontrado na literatura. A prevalência foi maior entre os pacientes com idade inferior a 29 anos, renda familiar baixa, maior tempo em hemodiálise, maior Kt/V e ingestão calórica e proteica inadequadas. Estratégias para reverter esta situação devem envolver maior atenção nutricional.

Termos de indexação: Desnutrição. Avaliação nutricional. Diálise renal.

\section{INTRODUCTION}

With a prevalence of 10 to $60 \%{ }^{1}$, malnutrition continues to be a problem in Chronic Renal Failure (CRF) patients on Hemodialysis (HD), increasing their morbidity and mortality ${ }^{1,2-5}$.

Factors that discourage food intake and promote hypercatabolism can lead to malnutrition. Among them are anorexia due to uremia, gastrointestinal disorders, psychological factors, severe dietary restrictions, social problems, comorbidities, inflammatory processes, and hypercatabolism due to nutrient losses during dialysis and metabolic changes ${ }^{6,7}$.
Detecting malnutrition in CRF patients is a challenge ${ }^{2}$. There is no single objective method capable of diagnosing malnutrition accurately in HD patients ${ }^{5}$. Biochemical and anthropometric indicators can be influenced by comorbidities, inflammatory status, hydration status, observer experience, and absence of reference standards for HD individuals ${ }^{8}$.

In this context, the Subjective Global Assessment (SGA) has been used to assess the nutrition status of HD patients ${ }^{9}$. This technique relates objective and subjective aspects of the clinical history and physical examination ${ }^{2}$. The SGA is inexpensive, quickly administered, requires little 
interviewer training, and has good reproductibility 4,10 , being recommended by the National Kidney Foundation-Kidney Disease Outcomes Quality Initiative (NKF-K/DOQI) ${ }^{10}$. Multicentric and longitudinal studies have claimed that the SGA is associated with morbidity, mortality, and hositalization ${ }^{1,2}$, and correlates well with anthropometric measurements ${ }^{4}$.

In addition to diagnosing nutritional status, identifying clinically controllable risk factors that promote nutritional deficits is very important for planning specific interventions ${ }^{9}$. However, given the multicausality of malnutrition in $\mathrm{CRF}^{6,7}$, one should consider the relationships between its determinants when implementing prevention, diagnostic, and control strategies.

Considering this logic, the magnitude of CRF in Brazil, its impacts on nutritional status, and the absence of data on the prevalence of malnutrition in HD patients in the Brazilian Midwest Region, especially Goiás, this study aimed to estimate the prevalence of malnutrition in an HD population and establish the determinants of malnutrition.

\section{METHODS}

This cross-sectional study with a proportional, stratified sample from ten centers representative of the HD population of the city of Goiânia (GO) collected data from May 2009 to March 2010.

The sample size was given by the number of municipal HD patients aged 18 years or more $(n=1,400)$, the prevalence of malnutrition, which varies from 10 to $60 \%$ in HD patients ${ }^{3-5}$, sample maximization to $50 \%$, confidence interval of $95 \%$, and error of $5 \%$. Hence, the estimated sample size was 302 patients. An extra 20\% was included to compensate for losses and refusals, totaling 362 individuals, of which 344 remained in the study. The remainder $(n=18)$ either dropped out or did not provide all the required information.
Considering the total number of patients in each clinic, the sample was selected by simple random sampling and consisted of clinically stable, not institutionalized males and females aged 18 years or more who had been undergoing hemodialysis for at least three months.

The exclusion criteria were: infections in the last three months, cancer, tuberculosis, acquired immunodeficiency syndrome, severe chronic obstructive pulmonary disease, severe cardiovascular disease, cerebrovascular disease, symptomatic heart failure classes III and IV, pregnancy, venous catheter dialysis, and diseases or situations that prevented anthropometric and food intake assessments, such as advanced bone diseases, stroke sequelae, physical disabilities, or amputated limbs.

The study collected socioeconomic, demographic, lifestyle, and anthropometric data, clinical history, and energy intake; administered the SGA; and performed laboratory tests. Four dieticians trained specifically for this study collected the data mentioned above using standard forms, pretested in a pilot study.

Nutritional status was classified according to the SGA, as recommended by the NKF-KDOQI ${ }^{10}$ and validated by Steiber et al. ${ }^{2}$ for HD patients. This protocol uses a 7-point scale to measure each one of the six SGA items (changes in body weight, energy intake, gastrointestinal symptoms, functional capacity, diseases and comorbidities that affect nutritional requirements, and physical examination to investigate subcutaneous fat loss, muscle mass loss, and presence of edema or ascites). The present study used the cutoff points recommended by the KDOQI, which classifies patients as nourished when the scores 6 or 7 prevail; mildly or moderately malnourished when the scores 3, 4, or 5 prevail; and severely malnourished when the scores 1 or 2 prevail10.

The study socioeconomic and demographic data included gender, age in full years divided into age groups, marital status (living with or without a partner), education level (no education, elementary grades $1-4$, elementary grades 5-8, 
high school, and higher education); and family income according to number of minimum salaries $(<2,2-5$, and $>5)$.

Lifestyle data included smoking status (nonsmoker, smoker, ex-smoker - those who had not smoked in at least six months), alcohol intake (regardless of beverage type or amount), physical activity during leisure time (yes or no), at home (performs or not physically-demanding chores), at work (has or does not have physicallydemanding tasks), and physical activity commuting (inactive if the patient uses a vehicle, or walks or bicycles for less than ten minutes) ${ }^{11}$. Individuals inactive in all four categories above were considered inactive, and those active in at least one category above were considered active.

The clinical history data taken from the patients' medical records and confirmed with their physicians included CRF etiology, presence of comorbidities, and HD vintage.

Six 24-hour dietary recalls, three of HD days and three of non-HD days, excluding Sundays, collected dietary data. A program based mainly on the Brazilian Food Composition Table developed specifically for this study (www.dbcheckout.com.br/nutri) calculated the mean energy intake for those six days. Protein intake was estimated by calculating the Protein equivalent of total Nitrogen Appearance (PNA) of the midweek dialysis ${ }^{10}$ as follows: PNA (g/day):

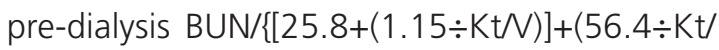
V) $\}+0.168$, where BUN, Blood Urea Nitrogen in $\mathrm{mg} / \mathrm{dL}=$ blood urea $(\mathrm{mg} / \mathrm{dL}) \div 2.14$. The result was normalized to the ideal weight as recommended by NKF-KDOQI ${ }^{10}$ and European Best Practice Guidelines (EBPG) ${ }^{12}$. A normalized PNA (nPNA) $>1.0 \mathrm{~g} / \mathrm{kg}$ was considered adequate ${ }^{12}$.

Two dieticians took the anthropometric measurements after the midweek dialysis as recommended by Lohman et al..$^{13}$ and standardized the data as recommended by Habicht ${ }^{14}$. The measurements included weight, height, Mid-Arm Circumference (MAC), and Triceps (TST), Subscapular (SST), Biceps (BST), and Suprailiac Skinfold Thicknesses (SIST).
Body Mass Index (BMI) was given by the dry weight-to-height squared ratio, and nutritional status was classified as recommended by the World Health Organization (WHO $)^{15}$. Mid-Arm Muscle Circumference (MAMC) was given by the equation $M A M C=M A C(\mathrm{~cm})$ $\{3.14 \times[T S T(m m) \div 10]\}$, and the result by gender was compared with the reference standards proposed by Frisancho ${ }^{16}$ and classified as recommended by Blackburn \& Harvey ${ }^{17}$.

Body fat was estimated by adding the four skinfold thicknesses (TST, SST, BST, and SIST) using the body density equations proposed by Durnin $\&$ Womersley ${ }^{18}$. The percentage of body fat was given by the equation proposed by Siri' ${ }^{19}$. Since no ideal percentage of body fat has been established for HD patients, the cutoff points used by the present study were up to 25 and $32 \%$ of males' and females' body weight, respectively ${ }^{20}$.

The biochemical tests included serum albumin (colorimetric method using bromocresol green) before dialysis, creatinine, and urea (kinetic method) before and after dialysis. All tests were performed by the clinical analysis laboratory of the Hospital das Clínicas of the Universidade Federal de Goiás (HC/NFG). Serum albumin $>4 \mathrm{~g} / \mathrm{dL}$ and creatinine $\geq 10 \mathrm{mg} / \mathrm{dL}$ were considered normal12. Dialysis was considered adequate when the patient's Kt $N$ index $\geq 1.2^{21}$.

The data were entered twice in the program Epi Info 6.0 to check for consistency and analyzed by the statistical package Stata 8.0. The categorical variables were expressed as frequencies and percentages, and the continuous variables as mean and standard deviation after the Kolmogorov Smirnov test checked data normality $(p \geq 0.05)$.

The prevalence of malnutrition was calculated for each study variable. Simple Poisson regression investigated which factors, if any, were associated with malnutrition. Variables with a statistical significance $\leq 0.20$ were tested in multivariate analysis by Poisson regression with robust variance estimate, and the Wald test assessed statistical significance. The variables with $p<0.05$ remained in the final model. 
The project was approved by the Research Ethics Committee of HC/UFG ( $n^{\circ}$ 011/2009) and of the Santa Casa de Misericórdia of Goiânia ( ${ }^{\circ}$ 046/2009), and all participants signed an Informed Consent Form. The entire sample was being followed regularly by dieticians.

\section{RES U LTS}

Table 1 describes the demographic, clinical, and nutritional characteristics of the study sample $(n=344)$. The prevalence of malnutrition according to the SGA was $22.40 \%$. Malnutrition was either mild or moderate, regardless of gender $(p=0.92)$. Most malnourished individuals were males $(59.30 \%)$ with a mean age of $49.33 \pm$ 13.76 years; the main etiologies were hypertensive nephropathy (37.70\%) followed by glomerulonephritis (19.50\%) and diabetic nephropathy (15.70\%). High blood pressure was the most common comorbidity (66.40\%). The median BMI and serum albumin were appropriate,

Table 1. Demographic, clinical, and nutritional characteristics of hemodialysis patients according to their nutritional status classified by the subjective global assessment. Goiânia (GO), Brasil, 2010.

\begin{tabular}{|c|c|c|c|c|}
\hline Variables & Total & $\begin{array}{c}\text { Nourished } \\
n=267(77.60 \%)\end{array}$ & $\begin{array}{l}\text { Malnourished } \\
\mathrm{n}=77(22.40 \%)\end{array}$ & $p^{*}$ \\
\hline Gender & & & & $0.929^{*}$ \\
\hline Males (n/\%) & $204(59.30)$ & $158(77.45)$ & $46(22.55)$ & \\
\hline Females (n/\%) & $140(40.70)$ & $109(77.86)$ & $31(22.14)$ & \\
\hline Age (years) & $49.33 \pm 13.76$ & $50.07 \pm 12.94$ & $46.75 \pm 16.09$ & $0.062^{*}$ \\
\hline HD vintage (months) & $43(24.00-78.75)$ & $42(24-72)$ & $48(25-97.5)$ & $0.092^{* *}$ \\
\hline $\mathrm{Kt} N$ & $1.59 \pm 0.39$ & $1.55 \pm 0.38$ & $1.73 \pm 0.38$ & $<0.001^{*}$ \\
\hline CRF etiology (n/\%) & & & & $0.741^{*}$ \\
\hline Hypertensive nephropathy & $130(37.70)$ & $100(37.45)$ & $30(38.96)$ & \\
\hline Glomerulonephritis & $67(19.50)$ & $55(20.60)$ & $12(15.58)$ & \\
\hline Diabetic nephropathy & $54(15.70)$ & $39(14.61)$ & $15(19.48)$ & \\
\hline Not determined & $26(7.60)$ & $22(8.24)$ & $4(5.19)$ & \\
\hline APKD & $24(7.00)$ & $19(7.12)$ & $5(6.49)$ & \\
\hline Others & $43(12.50)$ & 32 (11.99) & $11(14.29)$ & \\
\hline Comorbidities (n/\%) & & & & $0.427^{*}$ \\
\hline High blood pressure & $228(66.40)$ & $177(66.29)$ & $51(66.23)$ & \\
\hline Diabetes & $12(3.60)$ & $8(3.00)$ & $4(5.19)$ & \\
\hline High blood pressure + DM & $40(11.70)$ & $28(10.49)$ & $12(15.58)$ & \\
\hline Others & $13(3.40)$ & $1(4.12)$ & $2(2.60)$ & \\
\hline Inexistent & $51(14.90)$ & $43(16.10)$ & $8(10.39)$ & \\
\hline Weight (kg) & $64.04 \pm 12.85$ & $67.25 \pm 12.28$ & $52.91 \pm 7.46$ & $<0.001^{*}$ \\
\hline BMI $\left(k g / m^{2}\right)$ & $23.19(20.72-26.03)$ & $24.72 \pm 3.90$ & $20.00 \pm 2.55$ & $<0.001^{*}$ \\
\hline MAMC & & & & $<0.001^{*}$ \\
\hline$<5^{\text {th }}$ percentile & $82(23.80)$ & $37(13.90)$ & $45(58.40)$ & \\
\hline$\geq 5^{\text {th }}$ percentile & $262(76.20)$ & $230(86.10)$ & $32(41.60)$ & \\
\hline Body fat (\%) & $29.60 \pm 8.80$ & $31.55 \pm 7.93$ & $22.83 \pm 8.35$ & $<0.001^{*}$ \\
\hline LBM (kg) & $44.73 \pm 8.84$ & $45.85 \pm 8.95$ & $40.84 \pm 7.25$ & $<0.001^{*}$ \\
\hline Serum albumin ( $g / d L)$ & $4.01(4.0-4.3)$ & $4.13 \pm 0.27$ & $4.12 \pm 2.69$ & $0.642^{*}$ \\
\hline Pre-HD urea (mg/dL) & $110.84 \pm 27.52$ & $112.13 \pm 28.09$ & $106.38 \pm 25.14$ & $0.106^{*}$ \\
\hline Serum creatinine (mg/dL) & $9.50 \pm 2.62$ & $9.77 \pm 2.60$ & $8.57 \pm 2.53$ & $<0.001^{*}$ \\
\hline Energy intake (kcal/kg IW) & $26.05 \pm 6.64$ & $26.25 \pm 6.86$ & $25.33 \pm 5.80$ & $0.282^{*}$ \\
\hline nPNA (g/Kg IW) & $1.03 \pm 0.27$ & $1.05 \pm 0.27$ & $0.94 \pm 0.22$ & $0.001^{*}$ \\
\hline
\end{tabular}

Note: ${ }^{*} t$ test or Pearson's Chi-square test; ${ }^{* *}$ Mann Whitney test.

HD: Hemodialysis; KtV: Dialysis Adequacy Index; CRF: Chronic Renal Failure; APKD: Autosomal Polycystic Kidney Disease; DM: Diabetes Mellitus; BMI: Body Mass Index; MAMC: Mid-Arm Muscle Circumference; LBM: Lean Body Mass; IW: Ideal Weight; nPNA: normalized Protein Nitrogen Appearance. 
but mean serum creatinine was low $(9.50 \pm 2.62$ $\mathrm{mg} / \mathrm{dL}$ ). Based on BMl, $8.72 \%$ of the patients were underweight, 59.01\% were normal weight, and $32.27 \%$ were overweight. Most patients had appropriate serum albumin (77.91\%) and low serum creatinine $(58.72 \%)$.

In comparison with nourished patients (SGA), malnourished patients have smaller anthropometric parameters, namely body weight, $\mathrm{BMI}, \%$ of body fat, MAMC, and lean body mass $(p<0.001)$; higher $\mathrm{Kt} / \mathrm{V}(p<0.001)$; and lower serum creatinine $(p<0.001)$ and nPNA $(p=0.001)$ (Table 1).

The prevalence of malnutrition was significantly higher in patients aged 19 to 29 years $(50.00 \%)$ and in those with family income below

Table 2. Sample distribution, prevalence of malnutrition according to the subjective global assessment, and prevalence ratio of hemodialysis patients according to demographic, socioeconomic, and clinical variables, energy intake, and nPNA. Goiânia (GO), Brazil, 2010.

\begin{tabular}{|c|c|c|c|c|c|c|}
\hline \multirow{2}{*}{ Variables } & \multicolumn{2}{|c|}{ Sample distribution } & \multicolumn{2}{|c|}{ Prevalence } & \multirow{2}{*}{$\begin{array}{c}\text { Crude PR } \\
(95 \% \mathrm{Cl})\end{array}$} & \multirow{2}{*}{$p$-value } \\
\hline & $n$ & $\%$ & $n$ & $\%$ & & \\
\hline Age (years) & & & & & & 0.030 \\
\hline 19 to 29 & 24 & 6.98 & 12 & 50.00 & $1.24(1.06-1.44)$ & \\
\hline 30 to 39 & 62 & 18.02 & 14 & 22.58 & $1.01(0.91-1.13)$ & \\
\hline 40 to 49 & 88 & 25.58 & 17 & 19.32 & $0.98(0.89-1.09)$ & \\
\hline 50 to 59 & 84 & 24.42 & 16 & 19.05 & $0.98(0.89-1.09)$ & \\
\hline$>60$ & 86 & 25.00 & 18 & 20.93 & 1 & \\
\hline Education level & & & & & & 0.050 \\
\hline No education & 7 & 2.03 & 1 & 14.29 & $0.94(0.73-1.20)$ & \\
\hline Elementary grades 1-4 & 117 & 34.01 & 33 & 28.21 & $1.05(0.92-1.19)$ & \\
\hline Elementary grades $5-8$ & 104 & 30.23 & 14 & 13.46 & $0.93(0.82-1.05)$ & \\
\hline High school & 79 & 22.97 & 21 & 26.58 & $1.04(0.91-1.19)$ & \\
\hline Higher education & 37 & 10.76 & 8 & 21.62 & 1 & \\
\hline Marital status & & & & & & 0.093 \\
\hline Has partner & 203 & 59.01 & 39 & 19.21 & 1.00 & \\
\hline No partner & 141 & 40.99 & 38 & 26.95 & $1.06(0.99-1.14)$ & \\
\hline Family income & & & & & & 0.070 \\
\hline$<2 \mathrm{MS}$ & 161 & 46.80 & 44 & 27.33 & $1.12(1.01-1.25)$ & \\
\hline $2-5 \mathrm{MS}$ & 146 & 42.44 & 28 & 19.18 & $1.05(0.94-1.17)$ & \\
\hline$>5 \mathrm{MS}$ & 37 & 10.76 & 5 & 13.51 & 1 & \\
\hline$H D$ vintage & & & & & & 0.094 \\
\hline$\geq 60$ months & 128 & 37.21 & 35 & 27.34 & $1.00(0.99-1.15)$ & \\
\hline$<60$ months & 216 & 62.79 & 42 & 19.44 & 1 & \\
\hline$K t / V$ & & & & & & 0.005 \\
\hline$\geq 1.2$ & 288 & 83.72 & 71 & 24.65 & $1.12(1.03-1.22)$ & \\
\hline$<1.2$ & 56 & 16.28 & 6 & 10.71 & 1 & \\
\hline $\mathrm{kcal} / \mathrm{kg} \mathrm{IW}$ & & & & & & 0.002 \\
\hline$\geq 35$ & 29 & 8.43 & 2 & 6.90 & 1 & \\
\hline$<35$ & 315 & 91.57 & 75 & 23.81 & $1.15(1.05-1.27)$ & \\
\hline$n P N A(g / k g ~ I W)$ & & & & & & $>0.001$ \\
\hline Adequate $(\geq 1 \mathrm{~g})$ & 173 & 50.29 & 26 & 15.03 & 1 & \\
\hline Inadequate $(<1 \mathrm{~g})$ & 171 & 49.71 & 51 & 29.82 & $1.12(1.05-1.21)$ & \\
\hline
\end{tabular}

Note: *Wald test.

PR: Prevalence Ratio; 95\% Cl: Confidence Interval of 95\%; nPNA: normalized Protein Nitrogen Appearance; MS: Minimum Salary; HD: Hemodialysis; KtN: Dialysis Adequacy Index; IW: Ideal Weight. 
two minimum salaries $(27.33 \%)$, whose prevalence was 1.12 times higher than that of patients with family income above five minimum salaries. Malnutrition was also associated with $\mathrm{Kt} N$ above 1.2 (24.65\%). An energy intake below 35 $\mathrm{kcal} / \mathrm{kg} /$ day $(23.81 \%)$ and nPNA below $1.0 \mathrm{~g} / \mathrm{kg}$ (29.82\%) increased the prevalence of malnutrition by 1.15 and 1.12 times, respectively (Table 2 ). The variables gender, physical activity, smoking status, alcohol intake, comorbidities, and etiology were not associated with malnutrition and were not tested in the final multivariate analysis model ( $p>0.20)$.

Multivariate analysis included the following variables: age, education level, marital status, family income, $\mathrm{HD}$ vintage, $\mathrm{Kt} N$, energy intake, and nPNA. In the final multivariate analysis model, the following factors remained associated with malnutrition: age between 19 and 29 years ( $P R=1.23 ; 95 \% \mathrm{Cl}=1.06-1.43)$, family income below two minimum salaries $(P R=1.13$; $95 \% \mathrm{Cl}=1.01-1.20)$, longer $\mathrm{HD}$ vintage $(\mathrm{PR}=1.08$; $95 \% \mathrm{Cl}=1.01-1.16)$, energy intake below $35 \mathrm{kcal} / \mathrm{kg} /$ day $(\mathrm{PR}=1.22 ; 95 \% \mathrm{Cl}=1.10-1.34)$, and inappropriate nPNA (PR=1.13; 95\%Cl=1.05-1.21) (Table 3).

\section{DISCUSSION}

The prevalence of mild and moderate malnutrition in the study sample was $22.40 \%$ according to the SGA. This prevalence was lower than that found by Steiber et al. ${ }^{2}$, who found a prevalence of moderate malnutrition of $29.00 \%$ in $156 \mathrm{HD}$ patients, and higher than that found by the multicentric contrast study ${ }^{3}$, which used the same diagnostic method (SGA <6) and found a prevalence of moderate malnutrition of $17.00 \%$ in 560 patients. On the other hand, the percentage of malnourished patients in the present study was similar to that reported by the Netherlands Co-operative Study Adequacy of Dialysis II (NECOSAD-II), where $23.00 \%(n=1,601)$ of the patients were moderately malnourished'. Severe malnutrition defined by an SGA score of 1 or 2 also was not found by other studies ${ }^{2,3}$.

The prevalence of mild and moderate malnutrition found by earlier Brazilian studies
Table 3. Final multivariate analysis model of malnutrition in hemodialysis patients. Goiânia (GO), Brazil, 2010.

\begin{tabular}{|c|c|c|c|}
\hline Variables & Adjusted PR & $95 \% \mathrm{Cl}$ & $p$-value* \\
\hline \multicolumn{4}{|l|}{ Age (years) } \\
\hline 19 to 29 & 1.23 & $1.06-1.43$ & 0.006 \\
\hline 30 to 39 & 1.00 & $0.90-1.12$ & 0.929 \\
\hline 40 to 49 & 0.98 & $0.89-1.08$ & 0.713 \\
\hline 50 to 59 & 0.96 & $0.87-1.07$ & 0.485 \\
\hline$>60$ & 1 & - & - \\
\hline \multicolumn{4}{|l|}{ Family income } \\
\hline$<2 \mathrm{MS}$ & 1.13 & $1.01-1.27$ & 0.020 \\
\hline 2-5 MS & 1.05 & $0.94-1.17$ & 0.356 \\
\hline$>5 \mathrm{MS}$ & 1 & - & - \\
\hline \multicolumn{4}{|l|}{ HD vintage } \\
\hline$<60$ months & 1 & & \\
\hline$\geq 60$ months & 1.08 & $1.01-1.16$ & 0.035 \\
\hline \multicolumn{4}{|l|}{$K t / V$} \\
\hline$\geq 1.2$ & 1.12 & $1.03-1.22$ & 0.010 \\
\hline$<1.2$ & 1 & - & - \\
\hline \multicolumn{4}{|l|}{ kcal/kg IW } \\
\hline$\geq 35$ & 1 & - & \\
\hline$<35$ & 1.22 & $1.10-1.34$ & $<0.001$ \\
\hline \multicolumn{4}{|l|}{$n P N A(g / k g ~ I W)$} \\
\hline Adequate ( $\geq 1 \mathrm{~g})$ & 1 & - & \\
\hline Inadequate (<1 g) & 1.13 & $1.05-1.21$ & 0.001 \\
\hline
\end{tabular}

Note: *Wald test.

PR: Prevalence Ratio; Cl: Confidence Interval of 95\%; nPNA: normalized Protein Nitrogen Appearance; MS: Minimum Salary; HD: Hemodialysis; IW: Ideal Weight; KtN: Dialysis Adequacy Index.

varied from 39.7 to $80.0 \%^{22-24}$. However, comparison with such studies is inconclusive because they either used other SGA classification methods ${ }^{22,23}$ or small sample sizes ${ }^{24}$.

Malnutrition in HD patients has complex etiology, possibly resulting from disease- and treatment-related factors that further reduce food intake and increase protein catabolism, such as age, poor dialysis, psychosocial problems, hormonal imbalances, comorbidities, metabolic acidosis, inflammatory processes, and HD-related nutrient losses. Early detection of nutritional changes is critical since severe malnutrition is harder to treat ${ }^{25}$. In the present study, the risk factors that determined nutritional inadequacies were age, family income, HD vintage, dialysis adequacy, energy intake, and nPNA. 
The younger individuals in the study sample were at greater risk of malnutrition, contrary to Burrowes et al. ${ }^{26}$, who found that older patients had worse nutritional status. Our younger patients had lower weight, BMI, percentage of body fat, and lean body mass, and the main etiology was glomerulonephritis (data not shown). The factors that possibly worsened the nutritional status of these younger adults were inadequate protein intake along with higher energy expenditure secondary to age and dialysis-related catabolism $^{6,7}$. In these cases the principal recommendations for correcting nutritional status are greater surveillance, proper food intake and more physical activity to increase body weight, especially lean body mass $5,6,9$.

The inverse relationship between malnutrition and family income reinforces the influence of the latter on nutritional status, exposing the individual to food insecurity and violating one of the principles of a healthy diet, which is guaranteed physical and financial access to appropriate food ${ }^{27}$. Poor access to appropriate food worsens nutritional status, decreases adherence to treatment, increases mortality, and reduces survival ${ }^{28}$.

Patients with $\mathrm{HD}$ vintage longer than five years were more likely to be malnourished, corroborating Chumlea et al. ${ }^{29}$, who found a direct association between long HD vintage and poor nutritional parameters. Additionally, hemodialysis is highly catabolic, promoting significant loss of essential nutrients, such as amino acids, proteins, vitamins, and glucose ${ }^{7}$. If these nutrients are not adequately replenished, nutritional status may worsen over time. Bohé \& Rennie $^{6}$ claim that individuals on dialysis three times a week lose $2 \mathrm{~kg}$ of lean body mass a year.

The prevalence of malnutrition was also higher in study individuals with adequate dialysis according to the Kt $\mathrm{N}$ index. Since malnourished individuals have smaller body volumes, they are susceptible to an increase in $\mathrm{Kt} N$, so the possibility of malnutrition exists even when dialysis is efficient $^{10}$. However, inadequate dialysis may indirectly compromise nutritional status, since underdialyzed patients with $\mathrm{Kt} / \mathrm{N}$ below $1.2^{21}$ can experience less hunger because of the accumulation of uremic toxins ${ }^{25}$. Nevertheless, some studies did not find associations between $\mathrm{Kt} \mathrm{N}$ and nutritional status or survival, and shorter HD sessions ( $<3$ hours/session) were associated with higher mortality, regardless of $\mathrm{Kt} / \mathrm{N}^{30,31}$. The Hemo study $(n=1,846)$ found that random patients receiving a high dialysis dose ( $\mathrm{K} t \mathrm{~N}$ 1.65) did not consume more energy and proteins than random patients receiving the standard dose (KtN 1.25); moreover, both groups experienced similar weight loss and serum albumin reduction ${ }^{32}$.

The factors mentioned earlier, namely age, income, and HD vintage, lead to low energy and protein intakes, which directly impact nutritional status. Inadequate food intake, which generally begins before the introduction of renal replacement therapy ${ }^{12}$, is one of the main determinants of worse clinical outcomes in these patients, promoting weight loss, decreasing survival, and increasing morbidity and mortality ${ }^{10,12}$.

Patients with inadequate energy and protein intakes had higher prevalence of malnutrition, suggesting that energy and protein deficits play an important role in malnutrition in dialysis patients. Low protein and especially energy intakes have been observed in HD patients ${ }^{24}$.

The vast majority of the study sample (91.57\%) ingested fewer than $35 \mathrm{kcal} / \mathrm{kg} /$ day; of these, $47.97 \%$ ingested fewer than $25 \mathrm{kcal} / \mathrm{kg} /$ day, and the nPNA of $49.71 \%$ was below 1.0 $\mathrm{g} / \mathrm{kg} /$ day. This is concerning because, according to the classical study by Slomowitz et al. ${ }^{25}, 35-45$ $\mathrm{kcal} / \mathrm{kg} /$ day are necessary to revert a negative nitrogen balance in individuals consuming fewer than $25 \mathrm{kcal} / \mathrm{kg} /$ day. At least $1.0 \mathrm{~g}$ of protein $/ \mathrm{kg} /$ day is necessary to replenish the nutrients lost in hemodialysis and achieve positive nitrogen balance in clinically stable patients ${ }^{12}$. Additionally, adequate energy intake prevents the use of protein for energy ${ }^{25}$.

Malnutrition has an objective repercussion on anthropometric and laboratory parameters, resulting in low body weight, fat store depletion, 
body protein loss, and low serum albumin and creatinine in HD patients ${ }^{9,25}$. These parameters were lower in the malnourished study patients, except for serum albumin. This indicates the importance of HD patients gaining body weight, especially lean body mass, because weight gain would imply better functional and immune statuses, greater independence, and lower malnutrition-related morbidity and mortality ${ }^{6}$.

One of the study limitations was the impossibility of analyzing an inflammatory marker capable of distinguishing between malnutrition and inflammation-induced malnutrition. Only eleven (14.29\%) of the malnourished study patients had serum albumin below $3.8 \mathrm{~g} / \mathrm{dL}$, suggestive of malnutrition and inflammation ${ }^{2}$, a prevalence lower than the $18 \%$ found by Steiber et al. ${ }^{2}$. Since most of the study population had serum albumin above $4 \mathrm{~g} / \mathrm{dL}$ and were not malnourished, inflammation probably had at most a small influence on their nutritional status. Another limitation is not having analyzed the residual diuresis of 27 patients to calculate PNA. However, PNA remained associated with malnutrition even when these patients' data were excluded from data analysis.

Another limitation is the use of the 24hour recall to investigate food intake since this instrument is subject to the interviewee's memory and collaboration, and to underreporting and overreporting. However, the use of six dietary recalls improved the accuracy of the food intake data because it reduced the intrapersonal daily intake variability ${ }^{33}$. The study strengths are the use of a sample representative of the HD population of Goiânia (GO) and analysis of the isolated effect of many factors that can impact the nutritional status of these patients.

\section{CONCLUSION}

The prevalence of malnutrition in the study population was high, corroborating the literature. The prevalence was greater in patients aged less than 29 years and in those with low family income, longer hemodialysis vintage, higher $\mathrm{Kt} N$, and inadequate calorie and protein intakes. Strategies to revert this situation should include greater nutritional care.

\section{CONTRIBUTORS}

ATVS FREITAS, IMF VAZ, and SF FERRAZ helped to conceive the study; collect, analyze, and interpret the data; and write the manuscript. MRG PEIXOTO helped to analyze and interpret the results and to write the manuscript. MIVM CAMPOS helped to interpret the data. All authors reviewed the manuscript.

\section{REFERENCES}

1. Mutsert R, Grootendorst DC, Boeschoten EW, Brandts H, Manen JGV, Krediet RT, et al. Subjective global assessment of nutritional status is strongly associated with mortality in chronic dialysis patients. Am J Clin Nutr. 2009; 89(3):787-93. doi: 10.3945/ ajcn.2008.26970

2. Steiber A, Leon JB, Secker $D, M c C$ arthy $M$, McCann $L$, Serra $M$, et al. Multicenter study of the validity and reability of subjective global assessment in the hemodialysis population. J Ren Nutr. 2007; 17(5):336-42. doi: 10.1053/j.jrn.2007.05.004

3. Mazairac AHA, Wit GA, Grooteman MPC, Penne EL, Weerd NC, Dorpel MA, et al. A composite score of protein-energy nutritional status predicts mortality in haemodialysis patients no better than its individual components. Nephrol Dial Transplant. 2011; 26(6):1962-7. doi: 10.1093/ndt/gfq643

4. Tapiawala S, Vora H, Patel Z, Badve S, Shah B. Subjective global assessment of nutritional status of patients with chronic renal insufficiency and end stage renal disease on dialysis. J Assoc Physicians India. 2006; 54:923-6.

5. Combe C, McCullough KP, Asano Y, Ginsberg N, Maroni BJ, Pifer TB. Kidney Disease Outcomes Quality Initiative (K/DOQI) and the Dialysis Outcomes and Practices Patterns Study (DOPPS): Nutrition guidelines, indicators, and practices. Am J Kidney Dis. 2004; 44(Suppl. 2):S39-46. doi: 10.1053/j.ajkd.2004.08.010

6. Bohé J, Rennie MJ. Muscle protein metabolism during hemodialysis. J Renal Nutr. 2006; 16(1):316. doi: 10.1053/j.jrn.2005.07.005

7. Chasot C, Von-Van C, Blanc C, Hurot JM, Jean G, Vanel $T$, et al. Stability of nutritional parameters during a 5-year follow-up in patients treated with sequential long-hour hemodialysis. Hemodial Int. 2006; 10(4):389-93. doi: 10.1111/j.1542-47 58.2006.00135.x 
8. Oliveira $C M C$, Kubrusly M, Mota RS, Silva $C A B$, Oliveira VN. Desnutrição na insuficiência renal crônica: qual o melhor método diagnóstico na prática clínica? J Bras Nefrol. 2010; 32(1):57-70.

9. Chumlea WC. Anthropometric and body composition assessment in dialysis patients. Semin Dial. 2004; 17(6):466-70. doi: 10.1111/j.0894-0959.2004.1 7607.x

10. National Kidney Foundation Kidney Disease Outcomes Quality Initiative. Clinical practice guidelines for nutrition in chronic renal failure. Am J Kidney Dis. 2000; 35(Suppl. 2):17-55.

11. Organización Panamericana de La Salud. Protocolo y directrices: conjunto de ações para la reducción multifactorial de enfermedades no transmisibles (CARMEN/CINDI). México: OPAS; 1997.

12. Fouque $D$, Vennegoor $M$, Wee $P$, Wanner $C$, Basci $A$, Canaud $B$, et al. EBPG guideline on nutrition. Nephrol Dial Transplant. 2007; 22(Suppl. 2):ii45-ii87. doi: 10.1093/ndt/gfm020

13. Lohman TG, Roche AF, Martorel R. Anthropometric standardization reference manual. Champagne (IL): Human Kinetics Books; 1988.

14. Habicht JP. Estandarizacion de métodos epidemiológicos cuantitativos sobre el terreno. Bol Oficina Sanit Panam. 1974; 76(5):375-84.

15. World Health Organization. Obesity: Preventing and managing the global epidemic. Geneva: WHO; 1997. Report of a WHO Consultation on Obesity.

16. Frisancho AR. New norms of upper limb fat and muscle areas for assessment of nutritional status. Am J Clin Nutr. 1981; 34(11):2540-5.

17. Blackburn GL, Harvey KB. Nutritional assessment as a routine in clinical medicine. Postgrad Med. 1982; 7(1):46-63.

18. Durnin JV, Womersley J. Body fat assessed from total body density and its estimation from skinfold tickness: Measurements in 481 men and women aged from 16 to 72 years. Br J Nutr. 1974; 32(1):77-9.

19. Siri WE. Body composition from fluid spaces and density analysis of methods. In: Brozek J, Henschel A, Editors. Techniques for measuring body composition. Washington (DC): National Research Council; 1961. p.223-44.

20. Lohman TG. Advances in body composition assessment. Current Issues in exercise science series. Champagne (IL): Human Kinetics; 1992.

21. The National Kidney Foundation Kidney Disease. Outcomes Quality Initiative Clinical practice guidelines for hemodialysis adequacy: Update 2006. Am J Kidney Dis. 2006; 48(1Suppl. 1):S13-97.

22. Oliveira CMC, Kubrusly M, Mota RS, Silva $C A B$, Oliveira VN. Desnutrição na insuficiência renal crônica: qual o melhor método diagnóstico na prática clínica? J Bras Nefrol. 2010; 32(1):57-70.
23. Calado IL, Silva AAM, França AKTC, Santos AM, Salgado-Filho N. Diagnóstico nutricional de pacientes em hemodiálise na cidade de São Luís (MA). Rev Nutr. 2009; 22(5):687-96. doi: 10.1590/\$1415-5 2732009000500009

24. Vegine PM, Fernandes ACP, Torres MRSG, Silva MIB, Avesani CM. Avaliação de métodos para identificar desnutrição energético-protéica de pacientes em hemodiálise. J Bras Nefrol. 2011; 33(1):55-61.

25. Stenvinkel $P$, Heimburguer $O$, Lindholm $B$, kaysen $\mathrm{GA}$, Bergstrom J. Are there two types of malnutrition in chronic renal failure? Evidence for relationships between Malnutrition, Inflammation and Atherosclerosis (MIA syndrome). Nephrol Dial Transplant. 2000; 15(7):953-60. doi: 10.1093/ndt/ 15.7.953

26. Burrowes JD, Cockram DB, Dwyer JT, Larive B, Paranandi L, Bergen C, et al. Cross-sectional relationship between dietary protein and energy intake, nutritional status, functional status, and comorbidity in older versus younger hemodialysis patients. J Renal Nutr. 2002; 12(2):87-95.

27. Brasil. Ministério da Saúde. Guia alimentar para a população brasileira: promovendo a alimentação saudável. Brasília: Ministério da Saúde; 2008. Série A. Normas e Manuais Técnicos.

28. Zambonato TK, Thomé FS, Gonçalves LFS. Perfil socioeconomic dos pacientes com doença renal crônica em diálise na região noroeste do Rio Grande do Sul. J Bras Nefrol. 2008; 30(3):192-9.

29. Chumlea WC, Dwyer J, Bergen C, Burkart J, Paranandi L, Frydrych A, et al. Nutritional status assessed from anthropometric measures in the HEMO study. J Renal Nutr. 2003; 13(1):31-8. doi: 10.1053/jren.2003.50003

30. Kalantar-Zadeh K, Supasyndh O, Lehn RS, McAllister CJ, Kopple JD. Normalized protein nitrogen appearance is correlated with hospitalization and mortality in hemodialysis patients with Kt/N greater than 1.20. J Renal Nutr. 2003; 13(1):15-25. doi: 10.10 53/jren.2003.50005

31. Miller JE, Kovesdy CP, Nissenson AR, Mehrotra R, Streja E, Wyck DV, et al. Association of hemodialysis treatment time and dose with mortality and role of race and sex. Am J Kidney Dis. 2010; 55(1):100-12. doi: 10.1053/j.ajkd.2009.08.007

32. Rocco MV, Dwyer JT, Larive B, Greene T, Cockram DB, Chumlea WC, et al. The effect of dialysis dose and membrane flux on nutritional parameters in hemodialysis patients: Results of the HEMO Study. Kidney Int. 2004; 65:2321-34. doi: 10.1111/ j.1523-1755.2004.00647.x

33. Willett W. Nutritional epidemiology. $2^{\text {nd }}$ ed. New York: Oxford University Press; 1998.

Received on: 11/4/2013

Final version on: 4/11/2014

Approved on: 5/6/2014 